\title{
„Niczyje” złoto na „naszej” ziemi. o Płuczkach Pawła Reszki
}

“Nobody's" gold on “our" land. Płuczki by Paweł Reszka

\author{
|Agnieszka Czyżak \\ Uniwersytet im. Adama Mickiewicza w Poznaniu \\ IORCID: 0000000189185264
}

\begin{abstract}
The main aim of the article is to analyze a reportage book titled Płuczki. Poszukiwacze $\dot{z} y d o w s k i e g o$ złota written by Paweł Reszka in 2019. The most important research contexts are changes of Polish common consciousness and anti-Semitism as its essential part. Nowadays, in the XXI century the history and memory of Holocaust is currently a real challenge for researchers, as well as for average readers.
\end{abstract}

Key words: Holocaust, anti-Semitism, Jewish gold, concentration camps

Streszczenie: Nadrzędnym celem artykułu jest analiza reportażowej książki Pawła Reszki Płuczki.Poszukiwacze żydowskiegozłota opublikowanej w 2019 roku. Najważniejszym kontekstem badawczym są przemiany polskiej świadomości zbiorowej w XX wieku oraz antysemityzm jako jej istotna część składowa. W XXI wieku historia i pamięć o Zagładzie nadal pozostaje wyzwaniem dla zarówno dla badaczy, jak i zwykłych odbiorców.

Słowa kluczowe: Zagłada, antysemityzm, żydowskie złoto, obozy koncentracyjne

Książka Pawła Piotra Reszki, której pełny tytuł brzmi Płuczki. Poszukiwacze żydowskiego złota (Reszka 2019), znalazła się w finałowej siódemce Nagrody Nike w roku 2020, w odróżnieniu od wcześniejszej, dotyczącej tego samego tematu, a budzącej niezwykle silne kontrowersje, publikacji Jana Tomasza Grossa i Ireny Grudzińskiej-Gross Złote żniwa (Gross 2011), pominiętej nawet na liście wstępnej „dwudziestki” kandydatów do tej nagrody. Złotym żniwom zarzucano przede wszystkim nierzetelność naukowego opracowania, co pozwalało odsuwać na margines (z wielką szkodą dla toczących się dyskusji na temat relacji polsko-żydowskich w czasie okupacji i po niej) trudne aspekty przywoływanych wydarzeń. W przypadku Płuczek mamy jednak do czynienia z reportażem rekonstruującym pamięć sprawców (i ich potomków) haniebnego procederu rozkopywania żydowskich grobów. 
W książce, podzielonej na sześć części, najbardziej porażająca emocjonalnie okazuje się pierwsza, złożona z zapisów wspomnień uczestników wydarzeń z lat 40., mieszkańców okolic Bełżca, obozu zlikwidowanego jeszcze przed zakończeniem wojny. Ludność z wiosek otaczających teren kaźni niemal natychmiast po jego zamknięciu zaczęła przeszukiwać miejsce Zagłady:

Bo zaraz, jak tylko ten obóz otwarli, jak tylko Niemce poszły, to w tych śmietnikach, co tam zostały, było kopami polskich pieniędzy. I jeszcze ich można było wymienić. I dużo ludzie znaleźli. A potem to chodzili i grzebali po całym placu. Nawet płytko i już coś wychodziło. Gdziekolwiek, widać, że rzucali, gdzie tylko mogły, te Żydy. Ci, co mieszkali blisko, to wiedzieli, że Niemcy doły kopali i że tam kości i popiół kładli. I tam zaczęli kopać (Reszka 2019, 16).

Pierwsza decyzja, by pójść i przeszukać obozowe śmietniki, okazywała się w ostatecznym rozrachunku przekroczeniem granic przyzwoitości, po którym kolejne akty profanacji wydawały się już tylko uczestnikom procederu „naturalną” koleją rzeczy.

„Poszukiwaczom złota” nie przeszkadzało to, że łup był najczęściej niewielki: kilka złotych zębów, pierścionek, kolczyki, czasem złote monety, ruble czy dolary. Legendą za to obrastały szczególnie udane zdobycze (pas lub podwiązka z zaszytymi pieniędzmi czy but z podobnie wypełnionym obcasem) oraz wyjątkowy spryt poszczególnych „kopaczy”. Od początku, co prawda, pojawiało się coraz bardziej powszechne przekonanie, że to bogactwo „niedorobne” (bo nie można się na nim prawdziwie dorobić), że powoduje wzrost liczby pijaków w okolicy (wielu prosto od pasera szło do najbliższej knajpy), że sprowadza klątwę (staje się przyczyną śmiertelnych wypadków, chorób i nieszczęść) - to jednak nie powstrzymało nadejścia kolejnych fal „rozkopywaczy grobów” ${ }^{1}$.

Współczesne zapisy wspomnień o tamtych wydarzeniach, opisy rozrytej i wielokrotnie przeszukiwanej przestrzeni obozów, pełnej coraz głębszych dołów, podobnie jak wciąż przechowywana pamięć o jednostkowych, a częściej gromadnych „wyprawach” hien cmentarnych - działaniach zawsze podejmowanych w nadziei na łatwy zarobek - przypominają zapisy poczynione przez Mordechaja Canina, przemierzającego tuż po wojnie (1946-47) Polskę „w przebraniu” angielskiego dziennikarza. W książce Przez ruiny i zgliszcza. Podróż po stu zgładzonych gminach żydowskich $w$ Polsce, zbierającej te notowane na gorąco obrazy, można znaleźć - na przykład - „wizję lokalną" pozostałości po obozie w Sobiborze:

Każdą piędź ziemi na terenie dawnego obozu i drogi od linii kolejowej przekopała okoliczna ludność. Chłop, który opowiada mi o tym prostymi słowami prymitywnego człowieka, wciąż wierzy, że gdyby się „dobrze wziąć do roboty”, to jeszcze

${ }^{1}$ Takie określenie widnieje na odwrocie słynnej fotografii z Treblinki, odnalezionej w archiwach IPN, a dokumentującej dzień obławy na obozowe hieny cmentarne w 1946 roku. W aneksie zatytułowanym Historia pewnej fotografii Reszka przypomina dzieje kontrowersji, jakie budziło to zdjęcie od czasu opublikowania go w Złotych żniwach. 
znalazłoby się jakieś skarby. Wokół tych potencjalnych „skarbów” krążą wszystkie myśli tego chłopa (...), miałem nawet wrażenie, że chłop mnie podejrzewa, iż przyjechałem tu na wykopaliska, szukać „skarbów”... (Canin 2018, 460).

Canin podsumowuje: „Widok Sobiboru nie różni się od przerażającego widoku wszystkich zniszczonych cmentarzy żydowskich w Polsce. Każdy wziął, co chciał, rozkopał, przeorał i zostawił na pastwę losu” (Canin 2018, 461).

Reszka (podobnie jak Canin) opisuje też szczególny proceder zaprzęgania Natury w celu ukrycia śladów zbrodni - popioły pomordowanych spływały z nurtem rzek, tonęły w okolicznych bagnach lub użyźniały sadzone na terenach poobozowych lasy. Ułatwiało to uznawanie szczątków zgładzonych Żydów oraz pozostałych po nich przedmiotów za rodzaj naturalnego „pokładu” gleby, który można eksplorować bez poczucia naruszania sacrum. Jak sformułował to jeden z bohaterów Płuczek: „Ziemia była nasączona złotem” (Reszka 2019, 39), można było zatem z niej to złoto „wypłukiwać”. Zapis tak wytwarzanej zbiorowej świadomości znaleźć można i w innych współczesnych reportażach przywołujących powojenne czasy. W artykule Hieny cmentarne z Auschwitz-Birkenau Igor Rakowski-Kłos odtwarza zeznania jednego ze strażników Muzeum w Oświęcimiu: „Miejscowi zrozumieli, że to żydowskie złoto trupom już się nie przyda (...) to była nasza ziemia, Niemcy nas wysiedlili, ale teraz znów jest nasza, powinna do nas wrócić ze wszystkim, co w sobie kryje” (Rakowski-Kłos 2020). Znajdowane w „naszej” ziemi skarby stawały się tym samym niekwestionowaną własnością szczęśliwego „znalazcy”.

W Płuczkach pojawiają się drastyczne opisy naruszania zbiorowych mogił, połączonego z trudnym do wyobrażenia przekroczeniem wszelkich zasad wspólnotowego życia. „Kopacze” okazywali się zdolni do czynów, których z pewnością nie popełniliby na którymkolwiek z „własnych” cmentarzy:

Włosy, ręce, palce, całe głowy. Smród niesamowity, ino na teren się weszło. Widziałem wykopany dół, wyciągali trupa, jeszcze żywe ciało. Jeden ręką za włosy trzymał i rydlem, znaczy szpadlem, walił w szyję, żeby głowę obciąć, bo jeszcze się trzymała korpusu. To właśnie była rąbanka. Bo rąbali. Potem szczękę wyłamał i do kieszeni. Po ząbku przecież nie wyjmował. I potem jeszcze brał kawałek chleba, słoninę, co ją miał w kieszeni w szmatę zawiniętą, i jadł w tym wszystkim, tymi ręcami, co grzebał (Reszka 2019, 43).

Trudno dziś zrozumieć, że takie działania były możliwe, podobnie jak trudno przyjąć do wiadomości, że były tak powszechne ${ }^{2}$.

Mechanizmy wypierania istoty dokonywanych czynów zasadzały się na odmowie ich oceny moralnej. Autor Płuczek notuje także wypowiedzi współczesnych potomków Żydów zamordowanych w Bełżcu, w słowach których dostrzec można próby zrozumienia przebiegu minionych zdarzeń:

\footnotetext{
${ }^{2}$ Najczęstszym tłumaczeniem trudniących się tym procederem, także tych, którzy złapani w milicyjnych obławach stawali z tego powodu przed sądem, było powtarzane wielokrotnie „wyjaśnienie”, że przekopywane przez nich mogiły nie były oznaczone jako miejsce pochówku. Co zastanawiające, zazwyczaj ogrodzenie terenu, postawienie ostrzegawczych tablic, a także postawienie symbolicznego choćby pomnika prowadziło do zaniechania (lub ograniczenia) świętokradczych działań - tak jakby konieczne było „oficjalne” zatwierdzenie statusu miejsca kaźni.
} 
Język, którym się posługujemy, też pomaga ukryć prawdziwą naturę rzeczy. Pełen eufemizmów pozwala działanie moralne obrócić w działanie moralnie neutralne. (...) Człowiek, który kopał na cmentarzu, by obrabować zamordowanych w obozie zagłady, nie grzebał w spalonych zwłokach, on przeszukiwał żużel albo węgiel, nie kawałkował łopatą ciał, tylko ciął rąbankę. Ten język chronił kopaczy przed nimi samymi. Pomagał podtrzymać iluzję, jesteśmy dobrzy, jesteśmy uczciwi, to nic takiego (Reszka 2019, 81).

Formułowane dziś wnioski pozwalają uogólnić diagnozę o niepojętej naturze ówczesnych mechanizmów wykluczania: „z moralności było wyłączone nie tylko przeszukiwanie zwłok. W czasie okupacji i po niej wyłączeni byli z niej Żydzi, cała grupa etniczno-religijna. Zabić Żyda nie było działaniem złym, tylko obojętnym moralnie" (Reszka 2019, 81). W takim ujęciu jakoby bardziej „zrozumiały” staje się powszechny proceder zawłaszczania żydowskiego mienia przez polskich sąsiadów. Jan T. Gross w książce Strach. Antysemityzm w Polsce tuż po wojnie ukazał procesy przyśpieszonych procesów przemian w polskiej zbiorowej świadomości, pozwalających bez poczucia winy zasiedlać opróżnione domy i mieszkania, korzystać z porzuconego dobytku. Jak podkreśla Gross, już w czasie okupacji doszło do szczególnej reifikacji żydowskich obywateli wspólnego państwa: „<<Urzeczowienie>> Żydów jeszcze i na tym polegało, że za życia traktowani byli jako, można by rzec, tymczasowi depozytariusze własności <<pożydowskiej>>" (Gross $2008,86)$. Ta odmiana antysemityzmu ufundowana została na odmowie przyznania człowieczeństwa ofiarom i uznaniu ich za istoty nieodwołalnie skazane na śmierć, przyjmowaną z reguły jako niepodważalny wyrok „sił wyższych”. Ułatwiała również powszechną odmowę zwrotu zagrabionego („przejętego”) mienia: przedmiotów, mieszkań, domów ich właścicielom, tym nielicznym ocalałym z Zagłady.

Paweł Reszka w kolejnych odsłonach swojej książki przywołuje opowieści niejako dopełniające przedstawiany obraz: o następnym pokoleniu „kopaczy” z lat 60., o milicyjnych obławach, o zasądzonych wyrokach. Ale też o procesie prowadzącym do upamiętnienia ofiar, o powstawaniu pomników, o pracach archeologicznych. Historie te pozwalają na szerszy ogląd zagadnienia, choć w rzeczywistości nie zmieniają istoty przekazu - wskazują jednak na istnienie postaw odmiennych od powszechnego unieważniania skali zbrodni oraz statusu ofiar, czynionego, by bez poczucia winy czy wstydu przejmować pozostałości po ich przerwanej egzystencji³. W części zatytułowanej Warkocz pojawia się zapis wspomnień jednego z pomocników zatrudnianych podczas prac wykopaliskowych w Sobiborze:

Napieramy, ale idzie bardzo opornie. Nie ma wyjścia. Wyciągamy wiertło. To warkocz. Oplótł się wokół, były na nim jeszcze resztki wapna. Miał trzydzieści centymetrów

\footnotetext{
${ }^{3}$ We wspomnieniach spisywanych przez autora Płuczek pojawiają się obrazy używanych przez lata pierścionków czy kolczyków wygrzebanych z obozowej ziemi, a nawet złotej koronki wstawionej, bez zrozumiałej przyczyny, dziecku: „Na początku to Kryśka szczyciła się tym zębem, my koło niej byli takie uniżone. Ale nie nosiła go za długo, w szóstej klasie na pewno, potem już nie. Zdjęła, bo zaczął jej się psuć od korzenia" (Reszka 2019, 45).
} 
długości. (...) Nie dałem wtedy po sobie nic poznać, ale to mną potwornie wstrząsnęło. Wciąż o tym myślałem. Nie mogłem przestać. Zacząłem czytać o Sobiborze. (...) Ciężko jest mi o tym mówić. Wiedziałem tylko, że miała jasne włosy. Kim była? Czyją córką? Jakie miała marzenia? Kim byli inni? (Reszka 2019, 152).

Takie fragmenty pokazują ludzkie odruchy tych, którym wiele lat po wojnie przyszło zmierzyć się z namacalnymi śladami Zagłady i którym takie „spotkanie” odmieniło perspektywę oglądu przeszłości.

Powstające współcześnie, już w XXI wieku, teksty próbują nade wszystko - i to w najrozmaitszy sposób - dokonywać przewartościowań w opowieściach o przeszłości, przywracać pamięć o zdarzeniach z czasów wojny w ich najtrudniejszym dla polskiej zbiorowej świadomości wymiarze: odkrywania społecznych i ideologicznych realiów Holokaustu. Proces powstawania polskiej „nowej szkoły historycznej”, której działania prowadzą do poszerzania pola widzenia oraz owych koniecznych przewartościowań w sferze wspólnotowej pamięci, nie przebiega bez zakłóceń i zbiorowego oporu. Jego najnowszy etap zarejestrowała Alina Molisak w tekście Polacy i Zagłada. Nowa szkoła historyczna (Molisak 2020), przywołując m.in. głośny medialnie fakt zakłócenia przez polonijne środowiska antysemickie konferencji naukowej w Paryżu w 2019 roku ${ }^{4}$. Powstają też jednak książki, których celem są osobiste rozrachunki z historiami rodzinnymi z czasów okupacji - jak, na przykład, Drzazga. Kłamstwa silniejsze niż śmierć Mirosława Tryczka, w której autor skupił się na wydobywaniu z niepamięci lokalnych opowieści o pogromach na Podlasiu oraz o rzeczywistym udziale polskich sprawców (a wśród nich własnego dziadka) w ich przebiegu.

Głośny stał się w roku 2020 wiersz Jacka Podsiadły Słup ze słów (Podsiadło 2020) zawierający wspomnienie o Baili Gertner, nastoletniej więźniarce Auschwitz. Poeta zderza w nim między innymi los brata Białki, powstańca w getcie warszawskim, który zginął w straceńczym boju z Niemcami, z „codziennością” reakcji sąsiadów na zesłanie dziewczyny do obozu:

Czarne Makabi.

Śmierć, sukinsyny.

I wino walki

do głów uderza

a w Domu Białki

ktoś już przymierza

jej sukienczyny

i jedną chustkę.

Serce dziewczyny

odmierza pustkę

${ }^{4}$ Molisak pisze: „Zbulwersowana zachowaniem zorganizowanej grupy polskiej publiczności francuska minister nauki i szkolnictwa wyższego Frédérique Vidal wysłała list protestacyjny swojemu polskiemu odpowiednikowi, Jarosławowi Gowinowi. Bezprecedensowe antysemickie wystąpienia towarzyszyły wydarzeniu akademickiemu, jakim była konferencja” (Molisak 2020, 135). Badaczka przywołała też postawioną podczas konferencji tezę Andrzeja Ledera, iż wiedza o Zagładzie nadal funkcjonuje w Polsce w stłumieniu i przemilczeniu, co ma poważne konsekwencje międzypokoleniowe, a zaobserwować można też obecnie „narastanie lęku przed prawdą o nas samych” (Molisak 2020, 135). 
równiutką porcją,

miarką codzienną.

Już jest na dworcu.

Żegnaj Kamienno.

Poetycki zapis krótkiego życia ocalałej z Zagłady, ale później zamordowanej podczas pogromu kieleckiego dziewczyny, stał się wyrazistym oskarżeniem polskiej wspólnoty - nie tylko o obojętność wobec jej losu podczas okupacji, ale i niepojętej przemocy, której doświadczyła wówczas, gdy usiłowała odnaleźć na gruzach dawnego świata swoje miejsce na ziemi (Tokarska-Bakir 2018, 29-30).

Druga wojna światowa okazuje się „niekończącą się historią” - jak brzmi tytuł numeru tematycznego „Tekstów Drugich” (2020, nr 3). Historia w takim ujęciu zdaje się pełnić funkcje służebne wobec teraźniejszości, wobec ponawianych prób znalezienia w przeszłości odpowiedzi na kluczowe dla współczesności pytania. Ewa Domańska stwierdziła: „To, czego szukamy w przeszłości, zależy od tego, co gnębi współczesność i coraz częściej poszukujemy w przeszłości człowieka, a może raczej człowieczeństwa (nawet w jego nieludzkim wydaniu)" (Domańska 2010, 20). Tym samym historia jako „ludzka samowiedza”, jako wiedza o zachodzących w czasie zmianach (politycznych, społecznych, ideologicznych, obyczajowych) pozwala przede wszystkim uzmysławiać, co znaczyło kiedyś i co znaczy dziś być człowiekiem - zarówno w sensie kulturowym, jak i gatunkowym. Jak przekonywał Dipesh Chakrabarty, istniejemy w nakładających się fragmentach przeszłości, w minionych światach, które nigdy nie są całkowicie stracone czy zapomniane. W ujęciu badacza, kondycja ludzi nowożytnych pozostaje w ścisłym związku czy nawet niemożliwym do rozsupłania zawęźleniu z przeszłością: „Żyjemy bowiem w supłach czasu, które próbujemy rozplątać, jakby były częściami węzła (w istocie w ten właśnie sposób możemy postrzegać chronologię)" (Chakrabarty 2010, 412). Przeszłości nie można zatem odrzucić, jako bezpowrotnie minionych, unieważnionych przez upływ lat zdarzeń, lecz należy skupić się na ich wciąż kształtującym zbiorową tożsamość wymiarze.

Porządkowanie historii w ujęciu chronologicznym nie tłumaczy przebiegu dziejów. Ważniejsze okazuje się wieloaspektowe badanie nawarstwiających się pokładów przeszłości i ponawiania prób ich zrozumienia, także na przekór funkcjonującym powszechnie wspólnotowym mitom. W studium zatytułowanym Zapomniane sobowtóry historii Ashis Nandy, w połowie lat 90. zeszłego wieku przekonywał, iż aktualny ogląd historii „definiuje nasz stosunek do naszych wcześniejszych tożsamości” i powtarzał za Orwellem: "Ci, którzy władają przeszłością, mają również we władaniu teraźniejszość" (Nandy 2010). Tym samym ci, którzy chcą posiąść prawo do kształtowania historii nas samych, mogą także próbować wejść w częściowe posiadanie naszych obecnych tożsamości - a trzeba pamiętać, iż bezwolne przyjmowanie wizji historii, tworzonej przez innych w określonym celu politycznym 
czy ideologicznym, narusza autonomię jednostki, otwiera tożsamość na cudzą ingerencję. Aktywny udział w teraźniejszości wymaga świadomego i krytycznego osądu przeszłości.

Odwiedziny na terenach dawnych obozów koncentracyjnych powinny przywoływać pamięć o ofiarach Zagłady. Pamiętać jednak należy także o „kopaczach”, którzy wyruszali tam w nadziei na łatwy zarobek uzbrojeni w łopaty, szpadle i sita; „przepłukiwano” na nich nie tylko żużel ze spalonych ciał, ale i kości pomordowanych. Reszka notował: „Rafa to sito o prostokątnym kształcie (...). Po wojnie rafy używane są też w Bełżcu. Zwyczajne, ogrodnicze, kupione w sklepie albo zrobione specjalnie do przesiewania kości” (Reszka 2019, 89). Nie można zapomnieć o użytku, jaki czynili „rozkopywacze" z tych zwykłych przedmiotów, gotowi niemal bez namysłu czy moralnych wahań naruszać groby pomordowanych.

Jacek Leociak, rozwijając wywiedzioną z koncepcji Pierre’a Nory wizję miejsc pamięci, wskazywał, jak ważne jest napięcie między historią a pamięcią, niszczącym ślady przeszłości biegiem wydarzeń a niezbywalną powinnością pamiętania:

W tak rozumianym miejscu pamięci manifestuje się zerwanie ciągłości, a zarazem kult ciągłości. Marzenie o pełni i kontemplacja braku, niedopełnienia, pustki. A także milczenia, które może być martwe, czy - jak to się mówi - „grobowe”, ale może być też - jak pisał Norwid - „głosów zbieraniem”. A więc zapowiedzią mówienia (Leociak 2017, 629).

Badacz - tworząc swoją Biografię ulic, opowieść o przestrzeni startego z powierzchni stolicy warszawskiego getta - stara się nakłaniać współczesnych do tego, by pamięć o najtrudniejszych momentach przeszłości nie podlegała unieważnieniu $\mathrm{w}$ milczącej zgodzie na ich zakłamywanie, lecz pozostawała punktem wyjścia do wciąż ponawianych rozważań nad wspólnotowym dziedzictwem.

Każdy z przywoływanych powyżej tekstów, w całości lub w wybranych fragmentach (a także z osobna czy w ułożonych przez nauczyciela konfiguracjach), może zostać wykorzystany na lekcjach poświęconych literaturze, kulturze i historii czasów II wojny światowej i okupacji, przede wszystkim jako ich współczesny kontekst. Ich przydatność w nowych interpretacjach lektur obowiązkowych (Borowskiego, Nałkowskiej) potwierdzają m.in. spostrzeżenia Marty Tomczok, która w artykule Mydło - mięso - opał. Granice fantazji polskich świadków Zagłady pisała o ironii i metonimii jako figurach retorycznych często obecnych w poholokaustowej prozie polskiej (Tomczok 2017, 340). Dzięki nim właśnie pisarze tworzyli iluzoryczne przedstawienia przeszłości z Polakami w roli „niewinnych” świadków Zagłady. W innym miejscu Tomczok zwraca uwagę na zmianę perspektywy w opowieściach tworzonych po roku 2000, a skierowanych do szerszych kręgów odbiorców:

narracje pojedwabieńskie określają raczej polską tożsamość zbiorową niż tożsamość żydowską, względnie odtwarzają obie te perspektywy, co powoduje, że dużo 
częściej trafiają się wśród nich opowieści fundamentalnie edukacyjne czy informacyjne o bardzo jasno zarysowanym i w jakiejś mierze także naprawczym potencjale (Tomczok 2015, 267).

Warto byłoby również zastanowić się nad kwestiami genologicznymi i współczesnymi (ponowoczesnymi) przemianami reportażu. Justyna Tabaszewska podkreślała we wstępie do numeru tematycznego „Tekstów Drugich"5, poświęconego tym zagadnieniom:

Reportaż reaguje więc na zmiany, jakie zachodzą w społeczeństwie, dostosowując do aktualnych oczekiwań społecznych zakres i formę podejmowanych tematów, a równocześnie zmuszony jest do reagowania na coraz poważniejszy kryzys zaufania oraz niechęć wobec kategorii faktu (Tabaszewska 2019, 17).

Dzisiejsze obrazy historii z czasów II wojny światowej z reguły służą rewizji zakłamań, uproszczeń i stereotypów, w które obfitowały jej wcześniejsze wersje, uzależnione od wielu czynników politycznych i ideologicznych. Analiza i interpretacja wskazanych tekstów pozwoli uświadomić uczniom skalę cywilizacyjnej katastrofy, jaka dokonała się w owym czasie, wskazać na jej przyczyny i skutki, uwrażliwić na cierpienie ofiar i wykształcić krytyczną postawę wobec stereotypów zbiorowej świadomości i „białych plam” wspólnotowej pamięci.

\section{Bibliografia:}

Canin Mordechaj, 2018, Przez ruiny i zgliszcza. Podróż po stu zgładzonych gminach $\dot{z} y d o w s k i c h w$ Polsce, Adamczyk-Garbowska A. (przeł.), Warszawa.

Chakrabarty Dipesh, 2010, Historie mniejszości, przeszłości podrzędne, Domańska E. (przeł.), w: Teoria wiedzy o przeszłości na tle współczesnej humanistyki. Antologia, Domańska E. (red.), Poznań.

Domańska Ewa, 2010, Wprowadzenie, w: Teoria wiedzy o przeszłości na tle współczesnej humanistyki. Antologia, Domańska E. (red.), Poznań.

Gross Jan Tomasz, 2008, Strach. Antysemityzm w Polsce tuż po wojnie. Historia moralnej zapaści, Kraków.

Gross Jan Tomasz, Grudzińska-Gross Irena, 2011, Złote żniwa. Rzecz o tym, co się działo na obrzeżach Zagłady Żydów, Kraków.

Leociak Jacek, 2017, Biografie ulic. O żydowskich ulicach Warszawy od narodzin po Zagładę, Warszawa.

Molisak Alina, 2020, Polacy i Zagłada. Nowa szkoła historyczna, „Teksty Drugie” 2020, nr 3.

Nandy Ashis, 2010, Zapomniane sobowtóry historii, Ambroży-Lis P. (przeł.), w: Teoria wiedzy o przeszłości na tle współczesnej humanistyki, Antologia, Domańska E. (red.), Poznań.

Podsiadło Jacek, 2020, Słup ze słów, https://wyborcz.pl/7,75517,25870629,slup-ze-slow.html (dostęp: 21.01.2021).

\footnotetext{
${ }^{5}$ Wiele tekstów zamieszczonych w tym numerze - „Teksty Drugie” 2019, nr 6, temat wiodący Reportaż ponowoczesny - może posłużyć także jako inspiracja do rozważań związanych z przemianami współczesnych obiegów komunikacyjnych. 
Rakowski-Kłos Igor, 2020, Hieny cmentarne z Auschwitz-Birkenau, https://wyborcza.pl/alehistoria/7,121681,25648347, hieny-cmentarne-z-auchwitz.html (dostęp: 21.01.2021).

Reszka Paweł Piotr, 2019, Płuczki. Poszukiwacze żydowskiego złota, Warszawa.

Tabaszewska Justyna, Forma i fakt. Wyzwania współczesnego reportażu, „Teksty Drugie" 2019, nr 6.

Tokarska-Bakir Joanna 2018, Pod klątwa. Społeczny portret pogromu kieleckiego, t. 1, Warszawa.

Tomczok Marta, Po Jedwabnem. Narodziny popularnej opowieści rozliczeniowej, „Poznańskie Studia Polonistyczne. Seria Literacka” 2015, nr 25 (45).

Tomczok Marta, Mydło - mięso - opał. Granice fantazji polskich świadków Zagłady, „Teksty Drugie” 2018, nr 3.

Tryczyk Mirosław, 2020, Drzazga. Kłamstwa silniejsze niż śmierć, Kraków.

\section{O Autorce:}

Agnieszka Czyżak - dr hab., prof. UAM w Zakładzie Poetyki i Krytyki Literackiej IFP UAM, badaczka literatury współczesnej, przede wszystkim powstałej po roku 1989. Współredaktorka tomów zbiorowych m.in.: Powroty Iwaszkiewicza (1999), PRL - świat (nie)przedstawiony (2010), Pokolenie „Współczesności”. Twórcy. Dzieła. Znaczenie (2016). Autorka książek Życiorysy polskie 1944-89 (1997), Kazimierz Brandys (1998), Na starość. Szkice o literaturze przełomu tysiacleci (2011), Świadectwo rozproszone. Literatura najnowsza wobec przemian (2015), Przestrzenie $w$ tekście, w przestrzeni tekstów. Interpretacje (2018), Pasja przemijania, pasja utrwalania. O dziennikach pisarek (2019, współautorstwo) oraz Przeciw śmierci. Opowieść o twórczości Wiesława Myśliwskiego (2019). 
